\title{
Anna Kruś
}

\section{Udział ewangelików augsburskich w kształtowaniu krajobrazu kulturowego Piotrkowa Trybunalskiego}

Głównym celem autorki artykułu jest analiza udziału luteranów w kształtowaniu krajobrazu kulturowego Piotrkowa Trybunalskiego. Analizie poddano elementy dziedzictwa materialnego tej denominacji w przestrzeni miasta oraz jego znaczenie dla rozwoju turystyki w mieście. Niniejsze rozważania dotyczą obszaru Piotrkowa Trybunalskiego przede wszystkim ze względów historycznych - parafia luterańska, erygowana w tym mieście pod koniec XVIII w., należy do najstarszych parafii ewangelickich na terenie dzisiejszego województwa łódzkiego. Jest to także jeden $\mathrm{z}$ nielicznych $\mathrm{w}$ skali województwa ośrodków miejskich, który wykorzystuje obecność i dziedzictwo mniejszości religijnych do promowania swojej różnorodności i bogactwa kulturowego.

Słowa kluczowe: protestantyzm, mniejszość religijna, krajobraz kulturowy, Piotrków Trybunalski.

\section{Wprowadzenie}

Współcześnie można zaobserwować wyraźny wzrost zainteresowania problematyką związaną z badaniami krajobrazu kulturowego. Jako przykład jednego z najstarszych przedmiotów badawczych w obrębie wielu dziedzin (w tym geografii), doczekał się on licznych naukowych rozważań, perspektyw badawczych oraz możliwości interpretacji. Warto podkreślić, iż już samo pojęcie krajobrazu kulturowego ma na polu polskiej geografii szczególne miejsce i długą tradycję.

Polscy naukowcy (M. Dobrowolska, J. Tyszkiewicz, F. Plit, T. Chmielewski, U. Myga-Piątek) mają wiele osiągnięć w dziedzinie ochrony krajobrazu kulturowego, ponadto propagują i koordynują interdyscyplinarne badania w tym zakresie. Zadania te pełni m.in. Komisja Krajobrazu Kulturowego Polskiego Towarzystwa Geograficznego (Klupsz 2016).

Przed nakreśleniem głównych założeń niniejszego artykułu oraz metod badań, wykorzystanych do jego realizacji, należy doprecyzować zakres pojęcia krajobra- 
zu kulturowego, na którego podstawie prowadzona będzie dalsza analiza. Autorka będzie interpretować krajobraz kulturowy, opierając się na proponowanej przez wymienioną wcześniej Komisję definicji autorstwa dwojga polskich badaczy (zob. Myga-Piątek 2001, 2012), brzmiącej następująco'

Krajobraz kulturowy jest wynikiem przekształcania krajobrazu naturalnego przez grupę lub kilka grup kulturowych i nakładania zróżnicowanych elementów kulturowych różnego wieku na tę samą rzeźbę terenu. [...] Krajobraz ten można rozumieć jako antropogenicznie ukształtowany fragment przestrzeni geograficznej, powstały w wyniku zespolenia oddziaływań środowiskowych i kulturowych, tworzących specyficzną strukturę, objawiającą się regionalną odrębnością, postrzeganą jako swoistą fizjonomię.

Przechodząc do omówienia istoty artykułu, warto podkreślić, że podjęta problematyka wpisuje się w nurt badań wielokulturowości w ujęciu geograficzno-historycznym. Omówienie udziału ewangelików augsburskich w kształtowaniu krajobrazu kulturowego na przykładzie miasta królewskiego, jakim był Piotrków Trybunalski, niesie ze sobą dwa zasadnicze cele. Przede wszystkim ukazuje udział mniejszości religijnej jako aktywnego podmiotu w procesie kształtowania krajobrazu kulturowego Piotrkowa Trybunalskiego - miasta, które na przełomie wieków uchodziło za wspólnotę języków, nacji i kultur. Jednym z najtrwalszych efektów jej działań na przełomie ostatnich dwóch stuleci pozostają widoczne do dziś w przestrzeni miasta relikty dziedzictwa ewangelickiego, zwłaszcza w jego wymiarze materialnym. W toku tych rozważań autorka pragnie także zasygnalizować drugi cel artykułu, którym jest omówienie współczesnych form wykorzystania dziedzictwa luteranów przede wszystkim poprzez jego wkomponowanie w sieć tematycznych szlaków turystycznych, przyciągających na przestrzeni ostatnich kilku lat coraz liczniejsze grono odwiedzających.

Opracowanie zostało przygotowane z wykorzystaniem metod z zakresu geografii historycznej, jak również socjologii i geografii religii. Artykuł oparto na materiałach źródłowych, zawartych w literaturze, oraz dokumentach stanowiących zasoby parafii luterańskiej i archiwum w Piotrkowie Trybunalskim. Ponadto wykorzystano liczne inne ogólnodostępne opracowania, takie jak broszury informacyjne, wydane przez Urząd Miasta Piotrkowa. Uzupełnienie stanowily zasoby internetowe oraz informacje pozyskane w trakcie wywiadów z proboszczem piotrkowskiej parafii luterańskiej, księdzem Wiesławem Żydlem, i jej członkami.

\footnotetext{
${ }^{1}$ http://www.krajobraz.kulturowy.us.edu.pl/krajobraz.php (6.06.2017).
} 


\section{Ewangelicy augsburscy w dziejach Piotrkowa Trybunalskiego Znaczenie luteranów dla historii i dziedzictwa kulturowego miasta}

Rozpatrując dzieje pojawienia się luteranizmu w Piotrkowie Trybunalskim, należy zaznaczyć, iż zanim u kresu XVIII w. do miasta dotarli pierwsi wyznawcy tej religii, w kraju dało się już zauważyć wpływy reformacji, biorącej swój początek w Niemczech. W Polsce rozpoczęła się ona w drugiej dekadzie XVI w., jednak we wczesnej fazie nie przyniosła znaczących rezultatów, a zakres kręgów społecznych, do których dotarła, był ograniczony (Rykała 2010, s. 84). Widoczny w kraju nowy żywioł religijny nie mógł jednak nie wywołać gwałtownej odpowiedzi ze strony rządzących, jako że naruszył panujący w tym czasie porządek monarchiczny i kościelny. Reformacja wywołała falę krytyki Kościoła rzymskokatolickiego, posiadającego w tym czasie znaczące wpływy i dochody. Rosło także napięcie między obywatelami, mającymi konkretne potrzeby duchowe, a Kościołem, który nie potrafił im sprostać w należyty sposób.

Pierwszym monarchą, który otwarcie przeciwstawił się założeniom reformacji, był Zygmunt I Stary. Od 1520 r. wydawał on kolejne edykty będące wyrazem sprzeciwu wobec nauk Marcina Lutra. Zbieżne z nimi zalecenia zawarte były też w dokumentach wydanych w 1523, 1525 i $1526 \mathrm{r}$. W podobnym tonie utrzymane były uchwały sejmu piotrkowskiego, grożącego konsekwencjami wobec obywateli, którzy nie powrócą do kraju z terenów, gdzie rozpowszechnione były nauki Lutra (Bukowski 1883, s. 490).

W odniesieniu do połowy XVI w. istotny dla podjętej tematyki pozostaje również fakt rozpatrywania na sejmie w Piotrkowie w 1555 r. projektu powołania kościoła narodowego w Polsce, co można by uznać za apogeum reformacji w Polsce. Na sejmie tym izba poselska, zdominowana prawie całkowicie przez protestantów (w większości kalwinów), przedłożyła królowi i senatowi własne protestanckie Wyznanie Wiary. Zażądała zwołania soboru narodowego i przeprowadzenia reformy kościelnej, której rezultatem miał być polski kościół narodowy, ustanowiony na zasadach reformacyjnych. Zaistniała wówczas realna szansa na powstanie w Polsce struktur kościelnych podobnych do struktur kościoła w Anglii, również niezależnego od papieża. Reakcją Kościoła katolickiego było wówczas osadzenie w kraju nuncjusza papieskiego. Skupił on wszystkie swoje starania, by nie dopuścić do zwołania soboru narodowego, a sprzymierzeńca znalazł w samym królu Zygmuncie Auguście (Tokarczyk 1988, s. 31).

W warunkach rozwoju ruchów reformacyjnych Piotrków pozostał przez długi czas miastem dość jednolitym pod względem wyznaniowym, czego wyrazem był 
minimalny udział ludności ewangelickiej w strukturze populacji miejskiej. Przywileje królewskie dla polskich miast, zabraniające osadnictwa innowierców, zasadniczo dotyczyły tylko ludności żydowskiej. W 1487 r. król Kazimierz Jagiellończyk wydał dla Piotrkowa przywilej zabraniający żydom handlu w mieście i na przedmieściach (Feinkind 1930, s. 18). Rozszerzył go następnie król Zygmunt II August, który nadał w 1569 r. przywilej De non tolerandis Judeis, zabraniający żydom osiedlania w Piotrkowie, pozwalając im jedynie na udział w handlu podczas jarmarków. Zakaz ten został złagodzony dopiero w 1679 r. przez króla Jana III Sobieskiego, który zezwolił żydom na rozwój gminy i budowę bożnicy na terenie sąsiadującej z miastem i powiązanej z nim funkcjonalnie Wielkiej Wsi (Pacelt 1989, s. 81-82). Brak natomiast źródeł historycznych, które wskazywałyby na formalny zakaz osiedlania się innych grup wyznaniowych, poza żydami, na terenie miasta (Żerek-Kleszcz 1989, s. 177). Nie stanowi to jednak podstawy do odrzucenia założenia, że niektóre prawa miejskie i ustawodawstwo cechowe stanowiły istotną barierę dla zasiedlania miasta przez przedstawicieli innowierców, w tym ewangelików, czego przykładem może być znane dziś streszczenie uniwersału Zygmunta III Wazy z 1621 r. W akcie tym król zalecał, aby nie przyjmować do prawa miejskiego żadnego cudzoziemca bez pisemnej zgody proboszcza. Zgodnie z dokumentem wydanym przez Jana Kazimierza w 1659 r. do konfraterni kupców mogły należeć wyłącznie osoby wyznania rzymskokatolickiego. W związku z tym prawem znane są przypadki konwersji na katolicyzm (np. kupca szkockiego Wilhelma Petersona w 1652 r.) jako warunek sine qua non przystąpienia do prawa miejskiego i gildii kupieckiej. Mimo tych ograniczeń Piotrków, ze względu na pełnione funkcje administracyjno-sądownicze i ich reperkusje gospodarcze, nie był miastem homogenicznym pod względem religijnym, a ewangelicy mieli wyraźny udział w populacji miasta już w okresie przedrozbiorowym. Według danych pochodzących z indagandy pruskiej w 1793 r. wśród 1947 mieszkańców miasta (bez przedmieść) odnotowano 1698 katolików (87,2\% ludności miasta), 234 ewangelików (12\% populacji) i 15 prawosławnych $(0,8 \%$ ludności Piotrkowa) (Baranowski 1989, s. 85). Według ustaleń J. Janczaka (1989, s. 245-246) po 1793 r. w warunkach administracji pruskiej doszło do zniesienia formalnych ograniczeń związanych z osiedlaniem się różnych grup wyznaniowych i ich udziałem w życiu gospodarczym miasta. W nowej sytuacji geopolitycznej stanowiło to przyczynek do dalszego rozszerzenia osadnictwa ewangelickiego w mieście, skutkującego ostatecznie powstaniem pod koniec XVIII w. parafii piotrkowskiej.

Prowadzone od połowy XVI w. przez kolejne dwa stulecia działania, będące odpowiedzią na nowy prąd religijny, zostały nazwane kontrreformacją (Tazbir 1996). Posunięcia przedstawicieli tego ruchu religijnego bardzo długo blokowały 
aktywność innowierców, w tym luteranów, w naszym kraju. Represje i prześladowania, których doświadczali przedstawiciele innych wyznań w Rzeczypospolitej trwały z różnym natężeniem aż do pierwszego rozbioru Polski. Wspólnoty protestanckie w Wolborzu i Bogdanowie (powiat piotrkowski), które uformowały się jeszcze w XVI w. pomimo niesprzyjających warunków, uległy zanikowi wskutek działań kontrreformacyjnych. Protestanci w okolice Piotrkowa przybyli ponownie w XVIII w. Mieli wówczas poparcie zaborczej administracji pruskiej i gospodarowali ziemię, opierając się na wzorcach i warunkach zabudowy na tzw. prawie pruskim. Pierwszymi w tych okolicach przybyszami wyznającymi luteranizm byli koloniści, którzy dotarli w XVIII w. na tereny obecnego powiatu piotrkowskiego. Do samego miasta przyjeżdżali początkowo ewangeliccy kupcy, rzemieślnicy oraz urzędnicy administracji pruskiej. Proces kolonizacji był najczęściej inicjowany przez szlachtę, czasami nawet przez władze kościelne. Do najstarszych osad protestanckich (które pojawiały się jeszcze przed zajęciem tych terenów przez Prusy) zaliczyć należy: Leonów k. Wolborza, Łaznowską Wolę, Bukowiec, Jarosty i wiele innych miejscowości zasiedlanych przez ewangelików, szczególnie licznych w obrębie dóbr rządowych ${ }^{2}$.

Kluczowe dla luteranizmu w tym mieście były lata 1793-1796. Są one uznawane za cezury potwierdzające stałą obecność protestanckiego kaznodziei w Piotrkowie oraz określające najbardziej prawdopodobny czas utworzenia parafii.

W świetle zebranych materiałów fakt założenia parafii piotrkowskiej w końcu XVIII w. sytuuje ją w grupie najstarszych parafii luterańskich na obszarze współczesnego województwa łódzkiego. Niestety kwerenda dostępnych źródeł nie pozwoliła na jednoznaczne rozstrzygniecie kwestii, kiedy dokładnie do tego doszło (ani akt fundacji piotrkowskiej parafii, ani kroniki parafialne nie zachowały się). Na najwcześniejszą datę - 1793 r. - na podstawie wpisu z akt stanu cywilnego wskazuje odtworzona współcześnie Kronika Parafii Ewangelickiej w Piotrkowie Trybunalskim ${ }^{3}$. Na 1793 r. powoływał się także w swoim opracowaniu jeden z proboszczów piotrkowskiej parafii, ks. prof. J. Gryniakow ${ }^{4}$.

${ }^{2}$ Kronika Parafii Ewangelickiej w Piotrkowie Trybunalskim, 2009, oprac. H. Gantzke, Piotrków Trybunalski (praca niepublikowana, rkps tego dokumentu znajduje się w zasobach Parafii Ewangelicko-Augsburskiej w Piotrkowie Trybunalskim).

${ }^{3}$ Autorka ma tutaj na myśli zapis dotyczący ślubu Fryderyka Schülera z Heleną Wolską, zawartego 30.12.1793 r. Nazwisko pastora jest jednak na tym dokumencie nieczytelne.

${ }^{4}$ Prof. dr hab. Jerzy Gryniakow (1925-1992) - proboszcz parafii piotrkowskiej w latach 1953-1991 oraz wykładowca Chrześcijańskiej Akademii Teologicznej; autor artykułu Przeszłość i teraźniejszość zboru piotrkowskiego, opublikowanego w „Kalendarzu Ewangelickim" z 1958 r. 
Historyczni badacze niemieckojęzyczni (E. Kneifel, E.H. von Busch) również nie byli w stanie wskazać dokładnego roku założenia piotrkowskiej wspólnoty parafialnej. E.H. von Busch w opracowaniu Beiträge zur Geschichte und Statistik yudes Kirchen- und Schulwesens der Ev.-Augsburg. Gemeinden in Königreich Polen nie wskazuje żadnej konkretnej daty erygowania parafii. W publikacji tej pojawia się jedynie następująca wzmianka: „Wydaje się, iż parafia powstała w czasach pruskich, utworzona przez rząd" (Bush 1867, s. 169).

Drugi z badaczy, E. Kneifel, w opracowaniu Die evangelisch-augsburgischen Gemeinden in Polen. Eine Parochialgeschichte in Einzeldarstellungen 15551939, opierając się na wspomnianym opracowaniu von Buscha, podejmuje próbę sprecyzowania daty lokacji parafii i podaje rok 1796 (Kneifel 1971). Niestety autor nie wyjaśnił, dlaczego powołuje się na ten konkretny rok.

Za najbardziej prawdopodobne należy uznać, że piotrkowska parafia została założona pomiędzy 1793 a 1796 r., co nie przekreśla hipotezy mówiącej, że jest ona jedną z najstarszych wspólnot luterańskich (obok m.in. parafii w Kutnie) na terenie współczesnego województwa łódzkiego. Ustalanie daty powołania parafii wyłącznie na podstawie wpisu $\mathrm{z}$ akt stanu cywilnego lub też faktu stałej obecności w Piotrkowie ewangelickiego kaznodziei, przy tak skromnej ilości materiałów źródłowych byłoby niewiarygodne. Fakty te nie musiały bowiem być jednoznaczne z erygowaniem parafii luterańskiej.

Dla uformowanej już organizacyjnie wspólnoty parafialnej nagląca stała się potrzeba uzyskania kościoła parafialnego i powołania urzędu pastora do sprawowania opieki duszpasterskiej (ciekawostkę stanowi fakt, że początkowo opiekę nad wspólnotą piotrkowskich ewangelików sprawowali kaznodzieje garnizonowi). Rozwiązanie tych problemów nastąpiło, jak już wspominano, pod koniec XVIII w. W 1786 r. w Piotrkowie w wyniku pożaru częściowo spłonęły zabudowania należące do zakonu pijarów - klasztor i kolegium pijarskie ${ }^{5}$. Zmusiło to zakonników do przeniesienia się w 1788 r. do budynków należących uprzednio do skasowanego klasztoru Jezuitów. Opuszczone zabudowania klasztorne przeznaczono na mieszkania prywatne dla mieszczan piotrkowskich. W tym czasie w opustoszałych budynkach nie przeprowadzano większych remontów. Również kościół po zakonie pijarów przy ulicy Rwańskiej 6 stał pusty.

W wydawanym w tym czasie czasopiśmie „Tydzień” (1884) odnajdujemy informację, że w styczniu 1795 r. zapadła decyzja o odsprzedaniu tego kościoła ewangelikom augsburskim. Akt kupna-sprzedaży tego obiektu wystawiony został wiosną 1796 r. Do fizycznego przejęcia obiektu doszło w 1797 r., po

\footnotetext{
${ }^{5} \mathrm{http} / /$ www.piotrkow.luteranie.pl/index.php/nasza-historia/historia-kosciola parafialne go/ (12.06.2017).
} 
wcześniejszym zdjęciu z kościoła święceń oraz usunięciu z niego szczątków zmarłych zakonników. Jednocześnie ewangelicy przystąpili do odpowiedniego przystosowania świątyni do potrzeb kultu luterańskiego. W tym okresie pozyskano także ziemie na pierwszy cmentarz grzebalny przy alei 3 Maja w Piotrkowie (Kronika Parafii... 2009).

Podczas wojen napoleońskich kościół został czasowo zajęty i był wykorzystywany przez armię. Początkowo mieścił się w nim wojskowy magazyn, a w $1813 \mathrm{r}$. - szpital dla żołnierzy rosyjskich. Parafia ewangelicka odzyskała świątynię w roku 1817. Piotrkowska wspólnota luterańska kilkukrotnie borykała się z problemem braku stałego duszpasterza. Posługę religijną sprawowali tutaj dorywczo pastorzy z Łasku, Brużyc k. Aleksandrowa oraz Iłowa. Około 1826 r. do parafii tej - razem ze wszystkimi filiałami oraz kantoratami - należały bardzo rozległe tereny, co mocno utrudniało pracę piotrkowskiemu pastorowi, będącemu nieustannie w rozjazdach. Niejednokrotnie brakowało także środków na wypłaty wynagrodzeń dla pastorów. W 1830 r. piotrkowscy ewangelicy zakupili plac sąsiadujący z kościołem $\mathrm{w}$ celu zbudowania $\mathrm{w}$ tym miejscu domu parafialnego. $\mathrm{Z}$ powodu trudnej sytuacji finansowej został wzniesiony dopiero w 1846 r. (Kronika Parafii... 2009).

Szczytowy rozwój (również liczebny) piotrkowskiej parafii przypada na dwie ostatnie dekady XIX w. Ewangelicy piotrkowscy zakorzenili się wówczas w strukturze społecznej miasta ze znakomitym dla niej skutkiem. Czynnie uczestniczyli w życiu publicznym, zakładali stowarzyszenia i różnego typu instytucje pożytku społecznego. Według statystyk pod koniec XIX w. ponad 60\% piotrkowskich ewangelików deklarowało polskie obywatelstwo i posługiwało się językiem polskim (Piotrków Trybunalski - Trakt Luterański... 2011).

Dla zboru piotrkowskiego okresy obu wojen światowych były bardzo boleśnie odczuwalne. Podczas pierwszej z nich (1914-1918) rozwój parafii został skutecznie zahamowany. Zwiększenie wysokości składki kościelnej uchroniło wspólnotę przed koniecznością sprzedaży domu parafialnego. Głównym problemem luteranów była niepewna sytuacja finansowa parafii oraz potrzeba wyposażenia kościoła w nowe organy. Dużo bardziej dotkliwe straty przyniosła II wojna światowa. W chwili jej wybuchu w Piotrkowie mieszkało ok. 5 tys. luteranów. Choć w czasie walk świątynia luterańska nie została zniszczona, to po 1945 r. na skutek wysiedleń liczebność wspólnoty bardzo się zmniejszyła: z kilku tysięcy wiernych w parafii pozostało zaledwie kilkaset osób. Na szczęście nie przestała ona funkcjonować, nawet w niełatwych dla mniejszości religijnych latach Polski Ludowej i w obliczu obu transformacji ustrojowych. W 1995 r. w Piotrkowie uroczyście obchodzono 200-lecie istnienia parafii ewangelickiej w tym mieście (Kronika Parafii... 2009) (ryc. 1, 2). 


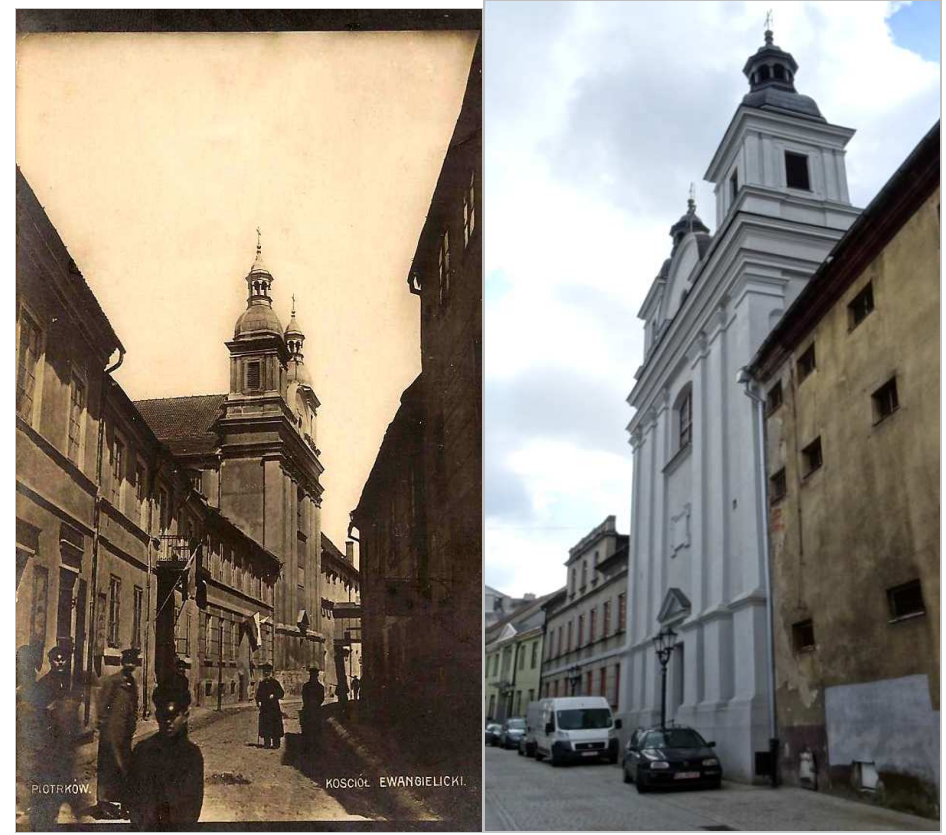

Ryc. 1. Kościół ewangelicki w Piotrkowie Trybunalskim na zdjęciu z lat 1910-1920 oraz współcześnie

Źródło: fot. A. Kruś (zdjęcie z prawej strony) oraz http://www.dawny piotrkow.pl/picture.php?/12968/category/140 (20.06.2017)

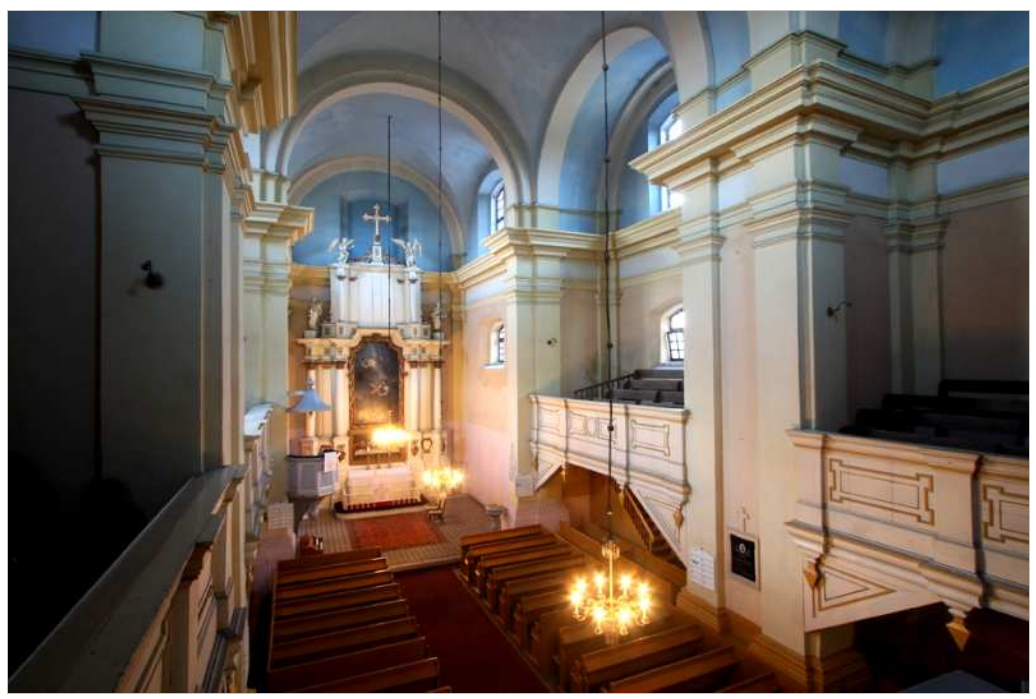

Ryc. 2. Wnętrze kościoła luterańskiego w Piotrkowie Trybunalskim Źródło: fot. A. Kruś 
Aspekty działalności piotrkowskich ewangelików, które na przełomie ostatnich 200 lat ukształtowały współczesne oblicze krajobrazu kulturowego Piotrkowa, omówiono w następnej części artykułu.

\section{Dziedzictwo ewangelików w Piotrkowie Trybunalskim}

Przez ponad 200 lat członkowie wspólnoty ewangelickiej w Piotrkowie Trybunalskim kształtowali krajobraz kulturowy tego miasta. Poza zadaniami związanymi stricte $\mathrm{z}$ działalnością religijną parafii wnieśli oni olbrzymi wkład w takie dziedziny życia społecznego, jak: szkolnictwo, dobroczynność i kultura.

W celu uporządkowania dalszej treści aktywność ewangelików piotrkowskich warto podzielić na inicjatywy parafialne (wewnętrzne) i społeczne (zewnętrzne). Co istotne, przedsięwzięcia te służyły całej społeczności miejskiej (bez względu na przynależność narodową lub wyznaniową) i świadczyły o wielkiej filantropii piotrkowskich ewangelików i ich niezwykłym przywiązaniu do małej ojczyzny, którą stał się dla nich Piotrków. Inicjatywy społeczne nie zostałyby podjęte bez zrealizowania w pierwszej kolejności dwóch najpilniejszych przedsięwzięć parafialnych ${ }^{6}$.

Pierwszą z inicjatyw parafialnych było wytyczenie miejsca na cmentarz. Został on założony w 1795 r., w obrębie placu przy Wrocławskim Przedmieściu (obecnie jest to odcinek ulicy Reymonta do alei 3 Maja). Cmentarz ten funkcjonował do 1830 r., kiedy decyzją władz miejskich wszystkie nekropolie zostały przeniesione poza granice miasta. Na tym cmentarzu pochówki odbywały się aż do jego zamknięcia w roku 1876 r. (ryc. 3), a sama nekropolia ostatecznie została zlikwidowana dopiero w 1995 r. Na nowym cmentarzu (przy obecnej ulicy Cmentarnej 14) rozpoczęto grzebanie zmarłych dopiero na przełomie 1876-1877 r., a więc niemal 50 lat od chwili jego założeniu, z uwagi na wcześniejszy brak funduszy na urządzenie i ogrodzenie nekropolii. W latach 80 . XX w. władze miasta przejęły tereny dawnego cmentarza ewangelickiego i rozpoczęły tam prace budowlane. Obecnie w tym miejscu znajduje się szkoła (Kronika Parafii... 2009, Piotrków Trybunalski - Trakt Luterański... 2011).

Drugą z inicjatyw parafialnych było wzniesienie domu parafialnego dla piotrkowskich ewangelików. Jego budowę przy ulicy Rwańskiej 6, na placu w sąsiedztwie kościoła, udało się ukończyć w 1846 r. (Piotrków Trybunalski - Trakt Luterański... 2011). Obiekt ten w dalszym ciągu należy do parafii, obecnie mieści się

\footnotetext{
${ }^{6}$ Rozmowa z proboszczem Parafii Ewangelicko-Augsburskiej w Piotrkowie Trybunalskim, ks. Wiesławem Żydlem, i jej parafianami, V 2017 r.
} 


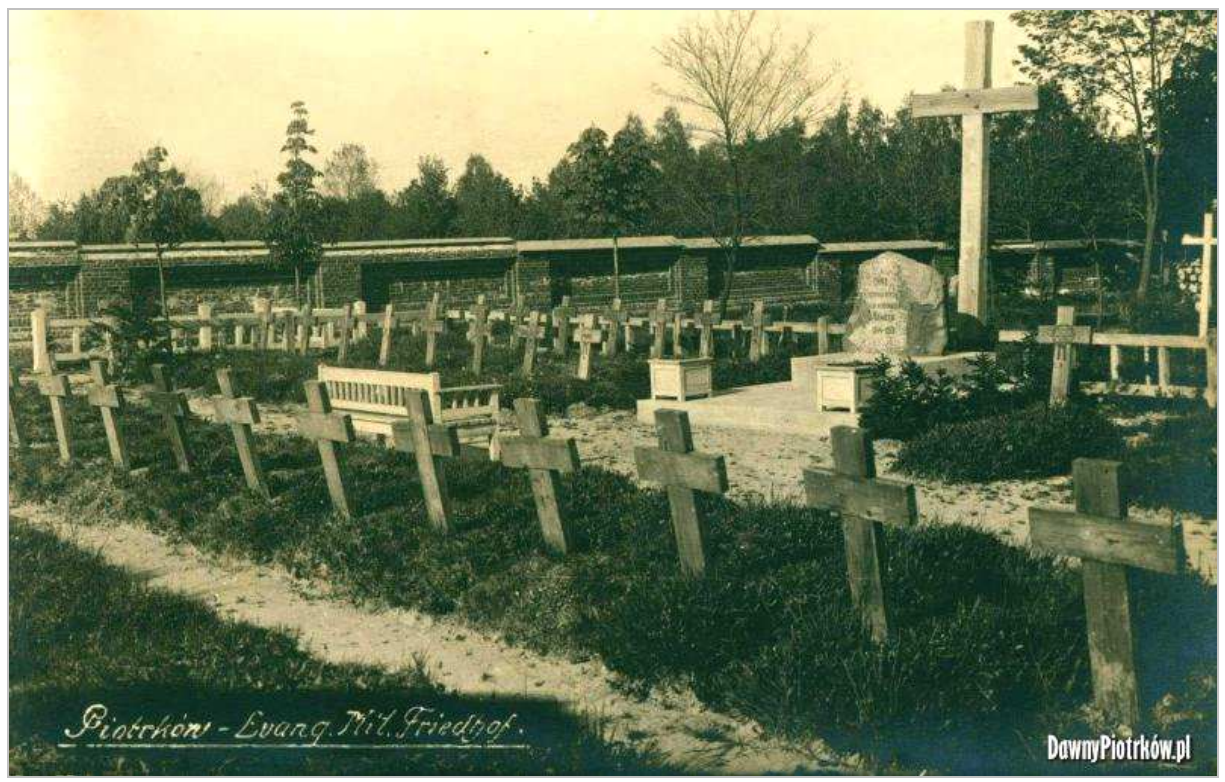

Ryc. 3. Cmentarz ewangelicki w Piotrkowie Trybunalskim - widok na kwatery wojenne Źródło: https://www.epiotrkow.pl/encyklopedia/C/Cmentarz-ewangelicki,76 (2.06.2017)

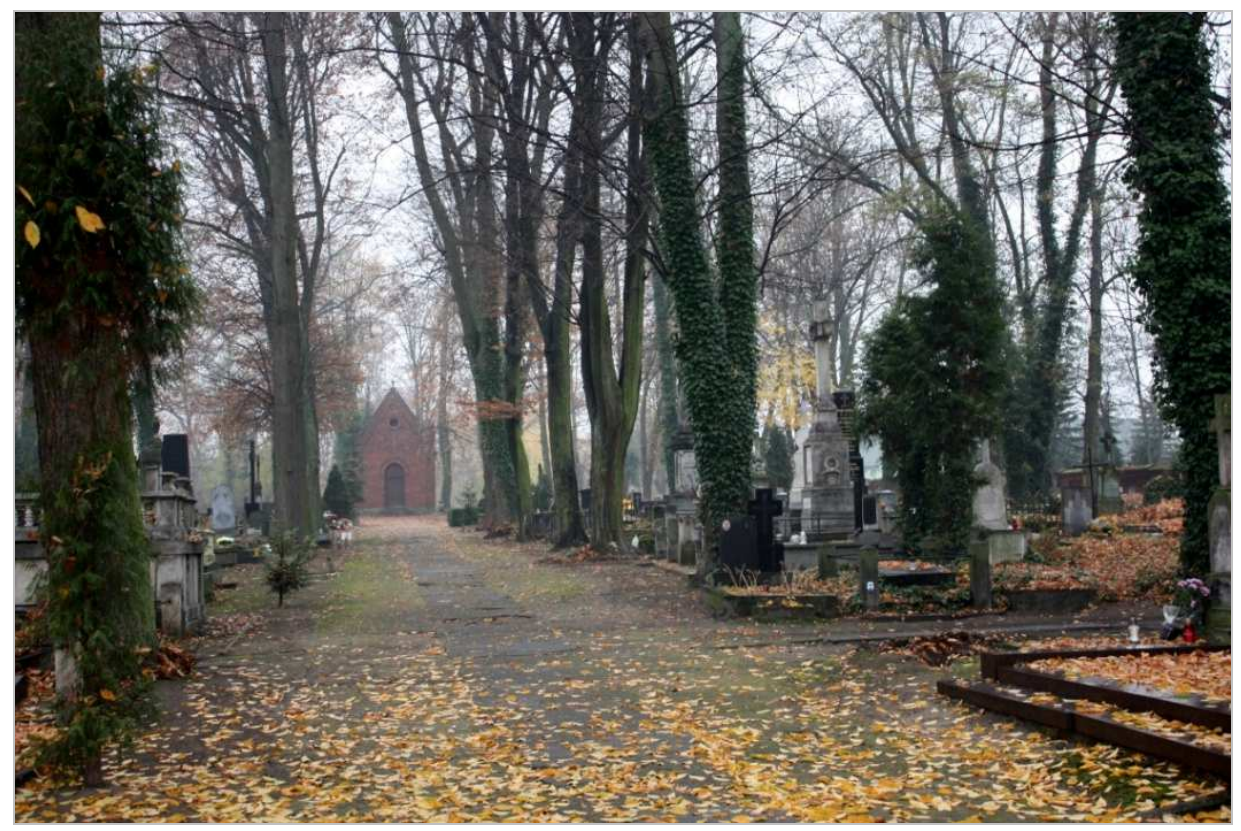

Ryc. 4. Cmentarz ewangelicki w Piotrkowie Trybunalskim - widok współczesny Źródło: fot. A. Kruś 
w nim m.in. sala parafialna oraz plebania. Parafia administruje również kamienicą przy ulicy Wojska Polskiego oraz kamienicą w Radomsku przy ulicy Reymonta $41^{7}$. Ustabilizowanie się sytuacji wspólnoty ewangelickiej w Piotrkowie pozwoliło luteranom na podjęcie zewnętrznych inicjatyw o charakterze społecznym. W czasie swojej ponad 200-letniej działalności ewangelicy piotrkowscy zainicjowali powstanie szkoły elementarnej, stołówki dla sierot i osób potrzebujących, chóru mieszanego, orkiestry dętej oraz powołali dwa stowarzyszenia społeczne - Ewangelickie Towarzystwo Dobroczynności (dzięki któremu w mieście założono dom starców) i Związek Młodzieży Ewangelickiej.

Ryc. 5. Dom parafialny w Piotrkowie Trybunalskim - widok współczesny Źródło: fot. A. Kruś

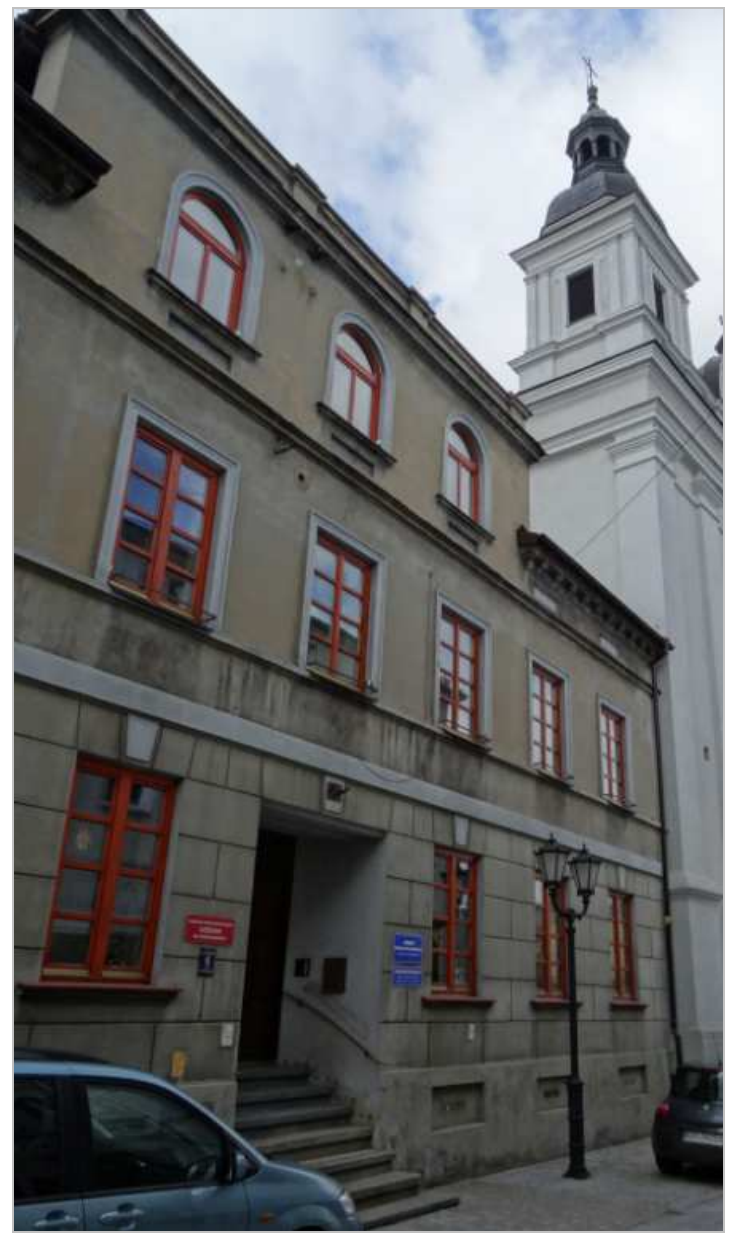

${ }^{7}$ Rozmowa z proboszczem Parafii Ewangelicko-Augsburskiej w Piotrkowie Trybunalskim, ks. Wiesławem Żydlem, i jej parafianami, V 2017 r. 
Jedną z najistotniejszych inicjatyw, które odmieniły oblicze Piotrkowa, był projekt powołania ewangelickiej szkoły elementarnej w $1846 \mathrm{r}$. Początkowo ze względu na brak środków pomysł ten nie został zrealizowany, jednak powrócono do niego sześć lat później - w 1851 r. Powstała wówczas rządowa szkoła elementarna ewangelicko-augsburska, umiejscowiona w budynku nowo powstałego domu parafialnego przy ulicy Rwańskiej 6 . W jej murach naukę pobierały dzieci nie tylko wyznania ewangelickiego, ale również mojżeszowego i rzymskokatolickiego. Gdy zwiększyła się liczba uczniów, siedzibę szkoły przeniesiono do budynku przy zbiegu ulic Mickiewicza i Wojska Polskiego. Z upływem lat szkołę tę zamieniono na placówkę ogólną, bezwyznaniową (Gryniakow 1958, s. 203-212). Pod koniec XIX w. przy parafii został powołany mieszany chór pod kierunkiem organisty Józefa Goleńskiego. Było to skuteczne antidotum na właściwie nieistniejące po klęsce powstania listopadowego życie kulturalne w mieście. Pozostając przy tym aspekcie życia społecznego, warto wspomnieć także o powołanej w $1920 \mathrm{r}$. kościelnej orkiestrze dętej, która nie tylko koncertowała w Piotrkowie, ale też brała udział $w$ imprezach regionalnych, takich jak np. zjazd orkiestr dętych w parafii św. Jana w Lodzi (Piotrków Trybunalski - Trakt Luterański... 2011).

Oblicze Piotrkowa zmieniały także ewangelickie związki i stowarzyszenia. W 1907 r. powstało w Piotrkowie Ewangelickie Towarzystwo Dobroczynności. Należało do niego kilkadziesiąt osób, które dobrowolnie opodatkowały się na rzecz pomocy osobom potrzebującym. Z inicjatywy członków Towarzystwa w siedzibie związku, tj. w należącej do parafii kamienicy przy dawnej ulicy Moskiewskiej (obecnie ul. Wojska Polskiego), założono dom starców dla kilkunastu pensjonariuszy. Obiekt ten funkcjonował nieprzerwanie (również w czasie II wojny światowej) aż do 1952 r., kiedy zabrakło na jego utrzymanie funduszy, a budynek przejęła administracja miejska. W pierwszej dekadzie XX w. dzięki zaangażowaniu parafian aktywowano także Związek Młodzieży Ewangelickiej (Kronika Parafii... 2009).

\section{Dziedzictwo luterańskie na obszarze Piotrkowa i formy jego wykorzystania (Noc Traktu Wielu Kultur, Trakt Luterański)}

Piotrków Trybunalski jest miastem, którego historię kształtowali reprezentanci wielu narodów, kultur i wyznań. By wykorzystać bogactwo tej mozaiki, władze miejskie stworzyły projekt o nazwie „Trakt Wielu Kultur”, będący częścią

\footnotetext{
${ }^{8}$ http://www.cit.piotrkow.pl/index.php/twk/168-jedno-miasto-wiele-kultur- (26.06.2017).
} 
zintegrowanych projektów rewitalizacyjnych, wpisanych do „Lokalnego programu rewitalizacji”. Bezpośrednim organizatorem spacerów w ramach tego projektu jest Centrum Informacji Turystycznej (ryc. 6). Trasa tego traktu wiedzie od dworca kolejowego (dawnego dworca Kolei Warszawsko-Wiedeńskiej) przez m.in.: Wieżę Ciśnień, cerkiew prawosławną, budynek sądu, dwa klasztory - oo. Bernardynów oraz ss. Dominikanek, mury obronne, Stare Miasto, kościoły ewangelicko-augsburski, oo. Jezuitów, farny, Instytut Badań nad Parlamentaryzmem, Zamek Królewski aż do Wielkiej Synagogi (obecnej Miejskiej Biblioteki Publicznej). Przemierzanie tego szlaku stało się jednym z punktów wpisanych w coroczny kalendarz turystyczny Piotrkowa.

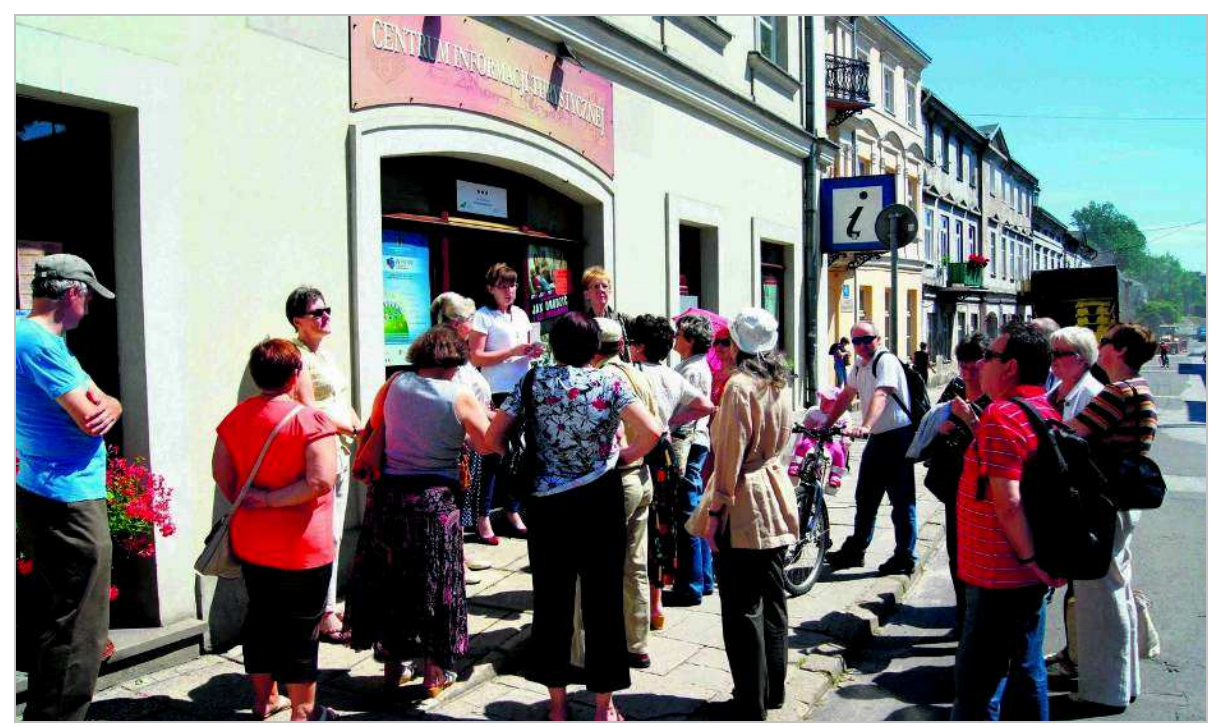

Ryc. 6. Centrum Informacji Turystycznej w Piotrkowie Trybunalskim - organizator spacerów w ramach projektu „Trakt Wielu Kultur” Źródło: http://piotrkowtrybunalski.naszemiasto.pl/tag/cit-piotrkowtrybunalski.html (23.06.2017)

W ramach działań mających na celu promowanie bogactwa kulturowego Piotrkowa, zostały również utworzone trakty turystyczne, nawiązujące do dziedzictwa poszczególnych grup kulturowych. Wśród tych szlaków można wyróżnić:

- Piotrków Trybunalski. Trakt Luterański,

- Piotrków Trybunalski. Trakt Rosyjski,

- Piotrków Trybunalski. Trakt Żydowski,

- Filmowy Piotrków,

- Piotrkowskie Kapliczki. 


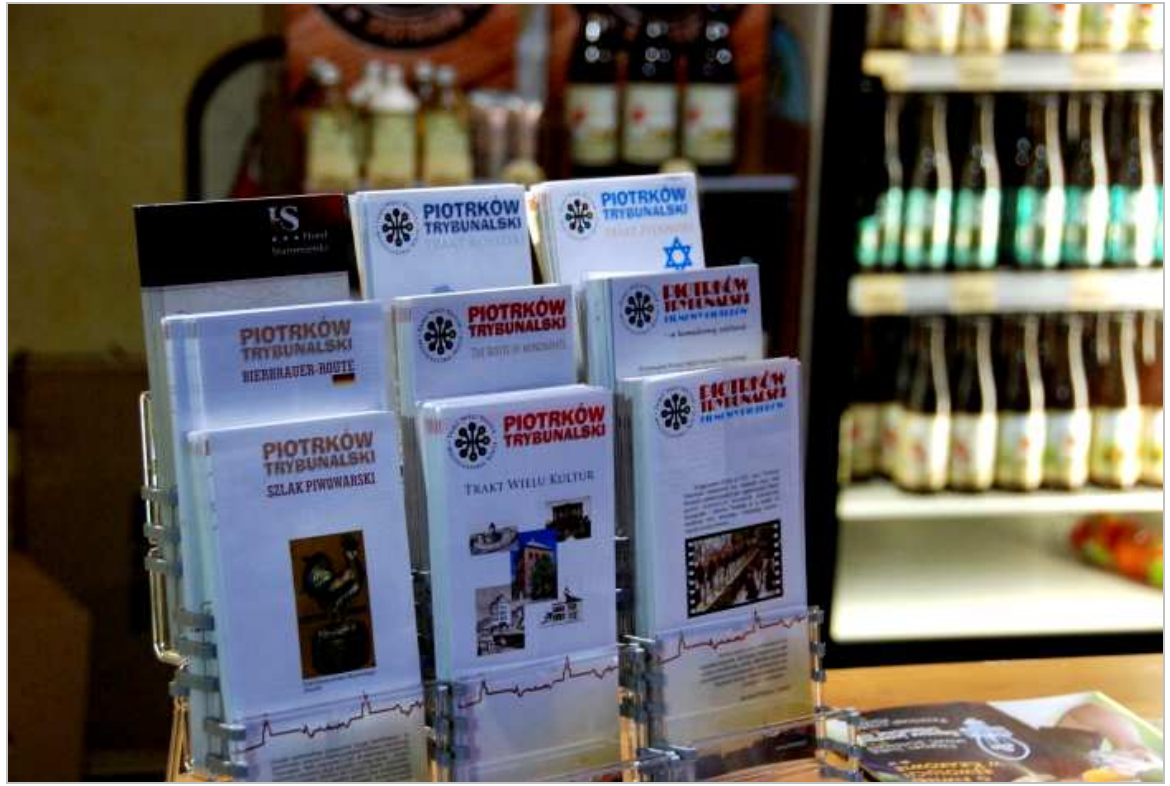

Ryc. 7. Materiały reklamowe promujące szlaki kulturowo-turystyczne w Piotrkowie Trybunalskim Źródło: fot. A. Kruś

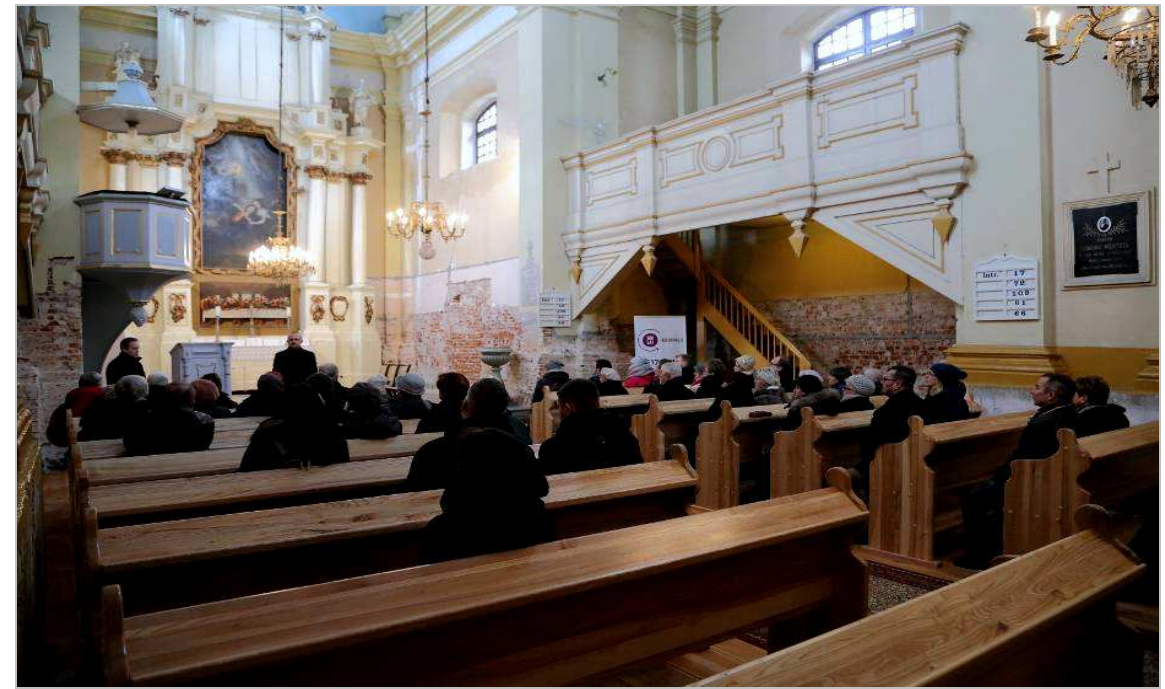

Ryc. 8. Wizyta w kościele ewangelickim w ramach przemierzania piotrkowskiego Traktu Luterańskiego - 2016 r.

Źródło: http://piotrkowtrybunalski.naszemiasto.pl/artykul/spacer-szlakiemewangelikow-w-piotrkowie-zdjecia,3654877,artgal,t,id,tm.html (22.06.2017) 


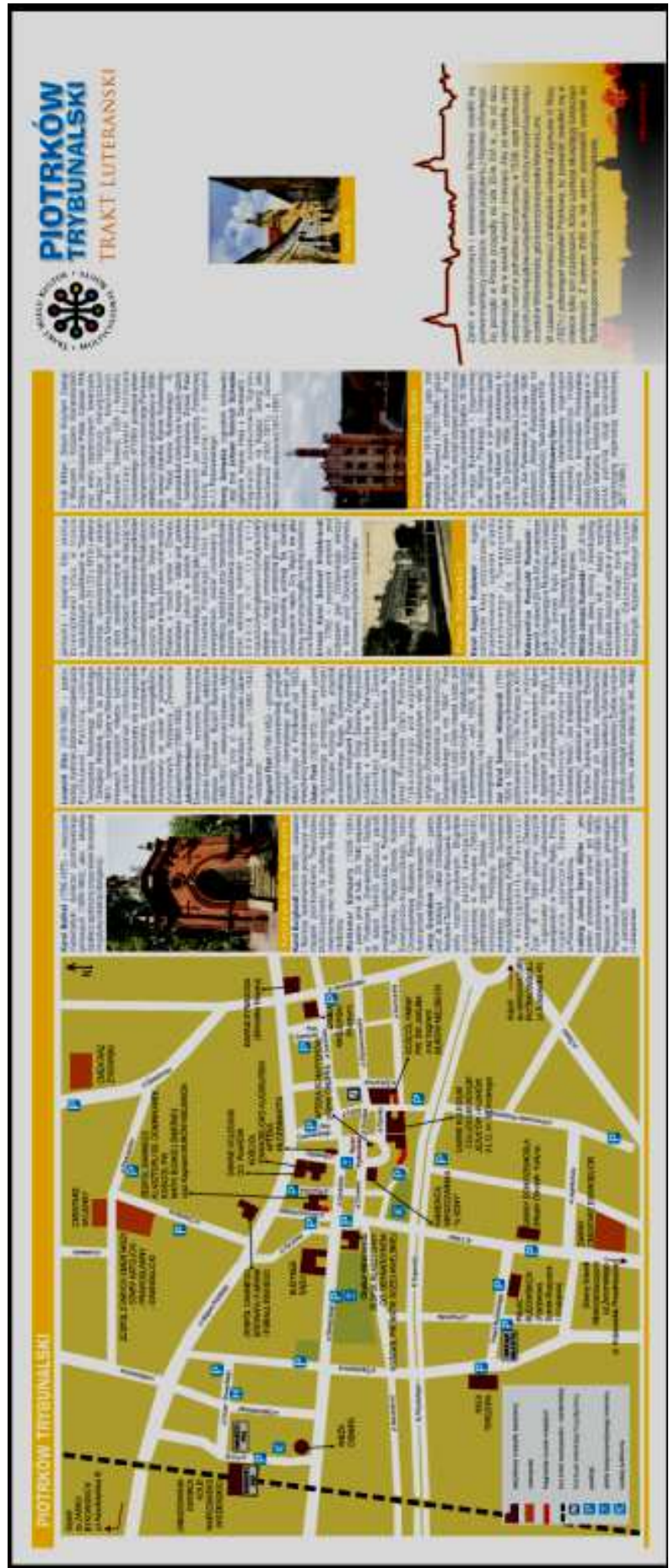

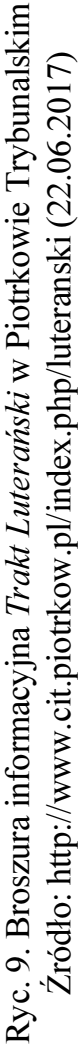


Przemierzając pierwszy z wymienionych traktów, zainteresowane osoby mogą się dowiedzieć, jak wiele obiektów, lokalizacji i postaci związanych z krajobrazem Piotrkowa Trybunalskiego należy łączyć z Kościołem luterańskim i jego wyznawcami. Przewodnicy podczas takich spacerów poruszają także tematykę tradycji, dziejów, kultury i obyczajowości piotrkowskich luteranów.

Projekt ten jest realizowany z powodzeniem od ok. pięciu lat i podobnie jak zwiedzanie innych tematycznych szlaków i traktów cieszy się w Piotrkowie sporą popularnością. O kolejnych edycjach tego spaceru cyklicznie informują internetowe portale miejskie i piotrkowska prasa. Na trasie bezpłatnego dwugodzinnego szlaku kulturowego uczestnicy mają okazję odwiedzić m.in. kościół ewangelickoaugsburski, cmentarz ewangelicki w obrębie kompleksu piotrkowskich nekropolii oraz dawną ewangelicką szkołę elementarną. Spacer ten rozpoczyna się przed siedzibą piotrkowskiego Centrum Informacji Turystycznej przy ulicy Zamurowej.

\section{Podsumowanie i wnioski}

Na przestrzeni wieków społeczność protestantów zajmowała szczególne miejsce na tle żyjącej w Piotrkowie mozaiki narodów i wyznań. Obecni w mieście od co najmniej trzech stuleci ewangelicy potrafili funkcjonować w obrębie wspólnej dla wszystkich przestrzeni, jak również pracować dla pożytku wszystkich mieszkańców miasta, wykorzystując konstruktywny dialog. Swoimi działaniami wspierali rozwój takich dziedzin życia społecznego, jak: szkolnictwo, kultura oraz dobroczynność, które na przełomie XVIII i XIX w. w obliczu powstań i zaborów przeżywały w mieście poważny kryzys lub w ogóle nie miały możliwości wykształcić się w nim. W sytuacji gdy społeczne działania mieszkańców, związane np. z życiem kulturalnym, były w dużej mierze zakazane lub kontrolowane, szansę na ich zaistnienie dawały inicjatywy podejmowane w murach kościoła protestanckiego. Przynosiły one poprawę jakości życia piotrkowian, wzbogacały jego krajobraz kulturowy, zacierały antagonizmy i uprzedzenia oraz stymulowały rozwój miasta właściwie aż do XX w.. Na drodze tej działalności stanęły obie wojny światowe, w tym II z nich, która położyła kres wielu wymienionym tutaj inicjatywom. W obliczu wysiedleń i prześladowań tej mniejszości po 1945 r., aktywność ta często była porzucana na kilkadziesiąt lat. Jej częściowa reaktywacja nastąpiła dopiero w latach 90.

Współczesne próby wykorzystania bogactwa kulturowego Piotrkowa do celów turystycznych mają charakter nowatorski i niezwykle innowacyjny. Zadaniem 
opisanego w artykule pomysłu stworzenia szlaku tematycznego jest ukazywanie walorów kulturowych lub elementów dziedzictwa kulturowego określonego miejsca lub regionu. To specyficzna forma obcowania $\mathrm{z}$ nasyconą kulturowo przestrzenią, skierowana do wąskiej grupy odbiorców, pragnących poznać szczegółowe zagadnienia z zakresu dziedzictwa kulturowego, oraz próba zwrócenia uwagi na znaczenie dziedzictwa kulturowego jako podstawowego składnika oferty turystycznej.

Z geograficznej perspektywy rozważań nad krajobrazem kulturowym projekt organizowania tematycznych szlaków i traktów w Piotrkowie Trybunalskim jest interesujący również z innych powodów - zwraca uwagę na różnorodność podmiotów kształtujących jego oblicze oraz przywraca pamięć o miejscach i obiektach niejednokrotnie zapomnianych lub mocno przekształconych. Szlaki i trakty kulturowe mają także wyraźny aspekt edukacyjny. W dalszej perspektywie pozwalają na powstawanie nowych produktów turystycznych (broszur, map, pocztówek, pamiątek itd.), opierających się przede wszystkim na lokalnym dziedzictwie kulturowym i stymulujących rozwój przestrzeni, na których znajduje się taki szlak. Warto zwrócić uwagę na fakt, iż Piotrków Trybunalski jest jedynym miastem w województwie łódzkim, które podjęło próbę stworzenia tego typu inicjatywy, mającej na celu promocję lokalnego dziedzictwa kulturowego.

\section{Literatura}

Baranowski B., 1989, Stosunki gospodarcze i spoteczne w drugiej polowie XVII w., [w:] Baranowski B. (red.), Dzieje Piotrkowa Trybunalskiego, Łódź, s. 84-96.

Bukowski J., 1883, Dzieje reformacyi w Polsce od wejścia jej do Polski aż do jej upadku, t. 1: Poczatki i terytoryalne rozprzestrzenienie się reformacyi, Kraków.

Busch E.H., 1867, Beiträge zur Geschichte und Statistik des Kirchen- und Schulwesens der Ev.-Augsburg. Gemeinden in Königreich Polen, St. Peterburg/Leipzig.

Feinkind M., 1930, Dzieje Żydów w Piotrkowie i okolicy: od najdawniejszych czasów do chwili obecnej, Piotrków.

Gryniakow J., 1958, Przeszłość i teraźniejszość zboru piotrkowskiego, „Kalendarz Ewangelicki z roku 1958", s. 203-212.

Janczak J., 1989, Ludność, [w:] Baranowski B. (red.), Dzieje Piotrkowa Trybunalskiego, Łódź, s. 239-263.

Klupsz L., 2016, Krajobraz kulturowy jako kategoria zabytków i jego specyfika, „Ochrona Dziedzictwa Kulturowego", 2 (16), s. 41-56.

Kneifel E., 1971, Die evangelisch-augsburgischen Gemeinden in Polen 1555-1939, Vierkirchen über München. 
Kronika Parafii Ewangelickiej w Piotrkowie Trybunalskim, 2009, oprac. H. Gantzke, Piotrków Trybunalski (praca nieopublikowana, rkps dokumentu znajduje się w zasobach Parafii Ewangelicko-Augsburskiej w Piotrkowie Trybunalskim).

Myga-Piątek U., 2001, Spór o pojęcie krajobrazu w geografii i dziedzinach pokrewnych, „Przegląd Geograficzny”, 73 (1-2), s. 163-176.

Myga-Piątek U., 2012, Krajobrazy kulturowe. Aspekty ewolucyjne i typologiczne, Katowice.

Pacelt K., 1989, Stosunki gospodarcze i spoleczne $w$ XVI $i$ w pierwszej polowie XVII w., [w:] Baranowski B. (red.), Dzieje Piotrkowa Trybunalskiego, Łódź, s. 73-83.

Piotrków Trybunalski - Trakt Luterański, 2011, druk ulotny wydany przez UM Piotrkowa.

Rykała A., 2010, Uwarunkowania geograficzno-polityczne oraz społeczne genezy i rozprzestrzeniania sie protestantyzmu $w$ Polsce, „Acta Universitatis Lodziensis. Folia Geographica Socio-Oeconomica", 10, s. 62-87.

Rzędowska A., 2008, Historia piotrkowskich Żydów: (do 1939 roku), Piotrków Trybunalski.

Tazbir J., 1996, Reformacja, kontrreformacja, tolerancja, Wrocław.

Tokarczyk A., 1988, Ewangelicy polscy, Warszawa.

„Tydzień”, 1884, 5.

Żerek-Kleszcz H., 1989, Życie religijne i kulturalne w XVI XVIII w., [w:] Baranowski B. (red.), Dzieje Piotrkowa Trybunalskiego, Łódź, s. 164-188.

\section{Źródła internetowe}

http://piotrkowtrybunalski.naszemiasto.pl/artykul/spacer-szlakiem-ewangelikow-wpiotrkowie-zdjecia,3654877, artgal,t,id,tm.html (22.06.2017).

http://piotrkowtrybunalski.naszemiasto.pl/tag/cit-piotrkow-trybunalski.html (23.06.2017).

http://www.cit.piotrkow.pl/index.php/luteranski (22.06.2017).

http://www.cit.piotrkow.pl/index.php/twk/168-jedno-miasto-wiele-kultur- (26.06.2017).

http://www.dawnypiotrkow.pl/picture.php?/12968/category/140 (20.06.2017).

http://www.krajobraz.kulturowy.us.edu.pl/krajobraz.php (6.06.2017)..

http://www.piotrkow.luteranie.pl/index.php/nasza-historia/historia-kosciola parafialnego/ (12.06.2017).

https://www.epiotrkow.pl/encyklopedia/C/Cmentarz-ewangelicki,76 (2.06.2017).

\section{Pozostałe źródła}

Rozmowa z proboszczem Parafii Ewangelicko-Augsburskiej w Piotrkowie Trybunalskim, księdzem Wiesławem Żydlem, i jej parafianami, maj 2015 r. 


\section{The role of the Evangelical Church in shaping the cultural landscape of Piotrków Trybunalski}

\section{Summary}

The main goal of the article is to analyze the role of Lutherans in shaping the cultural landscape of Piotrków Trybunalski. In addition, the elements of the material heritage of this denomination and its significance for the development of tourism in the town were analyzed. These considerations concern the area of Piotrków Trybunalski primarily for historical reasons - the Lutheran parish established in this town at the end of the $18^{\text {th }}$ century and it is one of the oldest Evangelical parishes in the present-day Lódź Province. It is also one of the few urban centers in the voivodeship, which uses the presence and heritage of religious minorities to promote their diversity and cultural richness.

Keywords: Protestantism, religious minority, cultural landscape, Piotrków Trybunalski.

Mgr Anna Kruś

Uniwersytet Łódzki

Wydział Nauk Geograficznych

Katedra Geografii Politycznej Historycznej i Studiów Regionalnych

90-142 Łódź, ul. Kopcińskiego 31

e-mail: anna.krus@geo.uni.lodz.pl 